\title{
Genetic and Molecular Characterization of R Plasmids Incompatible with R387 (IncK)
}

\author{
By HELMUT TSCHÄPE* AND ERHARD TIETZE \\ Institut für Experimentelle Epidemiologie, Burgstrasse 37, DDR-37 \\ Wernigerode, German Democratic Republic
}

(Received 26 July 1979; revised 26 October 1979)

\begin{abstract}
More than 70 conjugative $\mathrm{R}$ plasmids have been isolated from wild-type strains originating mainly in South-East Europe and identified as incompatible with the reference plasmid R387 of the incompatibility group K. These plasmids, governing different resistance patterns, have been characterized as P1 cotransducible species of between 50 and 60 megadaltons. In contrast to the genetic similarity between all these plasmids and the reference type R387, their DNA revealed different digestion patterns after EcoRI treatment, although a number of common fragments could be identified. The molecular and genetic properties of these plasmid species demonstrate a phylogenetic relatedness.
\end{abstract}

\section{INTRODUCTION}

Conjugative and non-conjugative plasmids need to be classified for epidemiological purposes. In the past few years a number of unrelated plasmid groups have been established based on their distinct genetic and molecular properties (Datta, 1975, 1979). Such groups comprise plasmids that have been shown to be mutually related, independent of their origin and the bacterial cell functions for which they code.

Using incompatibility and pili-specificity tests, molecular size determination, hybridization techniques and endonucleolytic cleavage analysis some of the plasmid groups such as FI, FII, C, P and $\mathrm{H}$ have been well-characterized, whereas others have not (Chabbert et al., 1972; Datta \& Hedges, 1973; Grindley et al., 1973; Sharp et al., 1973; Coetzee et al., 1972; Hedges, 1974; Grinsted et al., 1977; Burkardt et al., 1978; Roussel \& Chabbert, 1978; for review, see Datta, 1979). A number of the less well-characterized plasmid groups are represented only by a single or a few members (e.g. J, K) and investigations of plasmids from wild-type strains should provide additional members of these groups and thus enable comparative studies of the group-specific properties. Such investigations have been undertaken during the past few years and more than $70 \mathrm{R}$ plasmids have been isolated from Shigella flexneri, Shigella sonnei and Escherichia coli strains that are incompatible with R387, the reference plasmid and only representative of the K group (Hedges \& Datta, 1971).

In this paper we describe 10 plasmids representative of the many variants isolated. The results presented demonstrate that the plasmids, including the reference plasmid R387, share many genetic and molecular properties.

\section{METHODS}

Strains, plasmids and phages. Standard strains, plasmids and phages used are listed in Table 1. The plasmids studied, all incompatible with R387, were chosen to represent the different types characterized among more than 70 such plasmids isolated from wild-type strains originating in different countries and collected between 1975 and 1977. Details of these 10 plasmids and three deletion mutants are listed in Table 2.

Conjugation and transduction. The conjugation procedure was that described by Tschäpe (1973) and transduction using phage P1kc was done as described by Lennox (1955). 


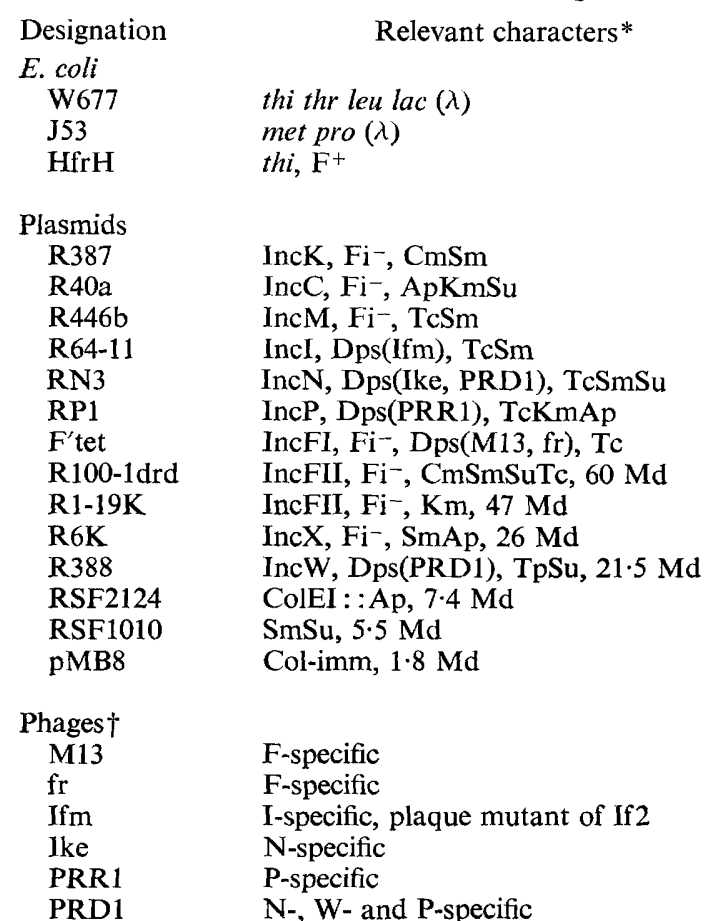

Source or reference

Clowes \& Hayes (1968)

Bachmann (1972)

Clowes \& Hayes (1968)

Hedges \& Datta (1971)

Datta (1975)

Datta (1975)

Datta \& Hedges (1973)

Datta (1975)

Grinsted et al. (1977)

Tschäpe (1973)

P. M. Bennett

P. M. Bennett

Kontomichalou et al. (1970)

Datta \& Hedges (1972)

So et al. (1975)

Guerry et al. (1974)

Meyers et al. (1976)

\section{Höhne}

M. Hoffmann-Berling

Tschäpe (1975)

Khatoon et al. (1972)

Olsen \& Thomas (1973)

Olsen et al. (1974)

* Abbreviations according to Bachmann (1972) and Datta (1979). Cm, Chloramphenicol resistance; $\mathrm{Sm}$, streptomycin resistance; Ap, ampicillin resistance; $\mathrm{Km}$, kanamycin resistance; $\mathrm{Tc}$, tetracycline resistance; $\mathrm{Su}$, sulphonamide resistance; Tp, trimethoprim resistance; Fi, fertility inhibition; Inc, incompatibility; Dps, donor phage specificity; Md, megadalton.

$\dagger$ Phage suspensions contained $10^{9}$ plaque-forming units $\mathrm{ml}^{-1}$.

Fi character. Fertility inhibition by the plasmids under investigation was tested in $\mathrm{HfrH}$. The plasmids were transferred by conjugation to $E$. coli $\mathrm{HfrH}$ and the ability of these $\mathrm{R}^{+}$transconjugants to produce $F$-pili was tested using the F-pili-dependent phage M13. At least 20 colonies per $\mathbf{R}+\mathbf{H}$ fr $\mathbf{H}$ strain were shown to be either sensitive $\left(\mathrm{Fi}^{-}\right)$or resistant $\left(\mathrm{Fi}^{+}\right)$.

Donor phage specificity. Escherichia coli $\mathrm{J} 53$ strains carrying the plasmids under investigation were tested for their sensitivity to the plasmid-specific phages M13, fr, Ifm, PRR1, PRD1 and Ike (Table 1) either by spotting the phages on to a lawn of $R^{+} J 53$ or by testing their ability to propagate the plasmid-specific phages (Lawn et al., 1967). As donor phage indicator strains we used $E$. coli J53 carrying the plasmids F'tet, R64-11, R388, RP1 and RN3, respectively (Table 1).

Incompatibility (Inc). Incompatibility was tested according to Coetzee et al. (1972) with the following modification. The plasmids under investigation were transferred by conjugation from $E$. coli W677 to $E$. coli J53 carrying the reference plasmids of the appropriate incompatibility groups (see Datta, 1975, 1979), or the reference plasmids were transferred to J53 clones carrying the plasmids under investigation. Fifty clones from each cross were tested for the presence of plasmids by replica-plating on to selective media after several subcultures in the presence or absence of a selective drug. As far as possible all plasmids under investigation were tested against one another.

DNA isolation and gel electrophoresis. Covalent closed circular (CCC) DNA of the plasmids was isolated by Triton X-100 extraction according to Thompson et al. (1974) and Grinsted (unpublished results) and by sodium dodecyl sulphate-NaCl precipitation as described by Meyers et al. (1976). A sample $(50 \mu \mathrm{l})$ of ethanolprecipitated and resuspended DNA was cleaved by EcoRI (Zimet, Jena, G.D.R.) as described by Barth \& Datta (1977) and was analysed together with an uncleaved sample $(50 \mu \mathrm{l})$ in a vertical slab gel $(0.3 \times 8 \times 15$ $\mathrm{cm}$ ) using $0.7 \%(\mathrm{w} / \mathrm{v})$ agarose (Marine Colloids, U.S.A.). Electrophoresis was carried out at $30 \mathrm{~mA}$ for about $3 \mathrm{~h}$ and then the gel was stained with ethidium bromide $\left(0.5 \mu \mathrm{g} \mathrm{ml}^{-1}\right)$ for $30 \mathrm{~min}$. The DNA bands could be observed under short-wave u.v. light using a UG5 filter (VEB Schott, Jena, G.D.R.). 
Table 2. Origin and resistance pattern of the representative plasmids

\begin{tabular}{|c|c|c|c|}
\hline Plasmid & Derivation or bacterial source & Country & $\begin{array}{l}\text { Resistance pattern* } \\
\quad \text { in } E \text {. coli } \mathrm{K} 12\end{array}$ \\
\hline pIE312 & Shigella sonnei & Bulgaria & TcCmSmSuApKm \\
\hline plE312l & Deletion mutant of pIE 312 & & $\mathrm{Tc}$ \\
\hline pIE 3122 & Deletion mutant of pIE 312 & & $\mathrm{TcCm}$ \\
\hline pIE3123 & Deletion mutant of pIE 312 & & $\mathrm{CmSmSuApKm}$ \\
\hline pIE313 & Shigella sonnei & U.S.S.R. & $\mathrm{TcCm}$ \\
\hline pIE316 & E. coli & G.D.R. & Tc \\
\hline pIE347 & E. coli & Bulgaria & TcCmAp \\
\hline pIE348 & Shigella sonnei & G.D.R. & $\mathrm{TcCm}$ \\
\hline pIE363 & Shigella flexneri & Bulgaria $\uparrow$ & TcCmSmSuAp \\
\hline pIE378 & Shigella flexneri & Bulgaria & Tc \\
\hline pIE379 & Shigella sonnei & U.S.S.R. & $\mathrm{TcSu}$ \\
\hline pIE380 & Shigella flexneri & Bulgaria & TcCmAp \\
\hline pIE381 & Shigella sonnei & U.S.S.R. & $\mathrm{TcCmSmSu}$ \\
\hline R387† & Shigella flexneri & Roumania & $\mathrm{CmSm}$ \\
\hline
\end{tabular}

Molecular weight determination. Molecular weights were determined assuming the relationship of DNA size to mobility established by Meyers et al. (1976). Plasmids R100-1drd, R1-19K, R6K, R388, RSF2124, RSF1010 and pMB8 were used as reference standards. The molecular weight standard for restriction fragments $(E c o$ RI) was phage $\lambda \mathrm{CI} / 857$ DNA which gives fragments of $13 \cdot 74,4 \cdot 74,3 \cdot 73,3 \cdot 48,3 \cdot 02$ and $2 \cdot 13$ megadaltons (Md) (J. Grinsted, personal communication). Results were averaged from at least three independent experiments.

\section{RESULTS}

\section{Genetic characterization}

The 10 selected plasmids (and the three deletion mutants derived from pIE312 after Plkc transduction) are representative of a group of more than 70 plasmids isolated between 1975 and 1977. They seem to be particularly distributed among Shigella strains originating in Bulgaria, U.S.S.R. and, recently, in G.D.R. (Table 2). All are cotransducible by bacteriophage Plkc which means that the majority of extransduced plasmids are genetically and molecularly identical to the donor plasmids. They can be transferred by conjugation to different members of the enteric bacteria, e.g. Salmonella, Klebsiella, Enterobacter, Rettgerella and Providencia. In addition, all the plasmids were $\mathrm{Fi}^{-}$, since all $\mathrm{HfrH}$ clones carrying them remained sensitive to the F-specific phages M13 and fr. Additionally, the plasmidharbouring $E$. coli $\mathrm{J} 53$ strains were insensitive to all plasmid-dependent phages (donor specific phages) such as M13, fr, Ike, Ifm, PRD1 and PRR1 either by the direct spotting test, or by propagation experiments.

In testing their incompatibility properties, all the plasmids showed a considerably reduced frequency of transfer (superinfection immunity) to E. coli J53 carrying R387 (Table 3), the reference plasmid of incompatibility group $\mathrm{K}$, compared with transfer to plasmid-free E. coli $\mathrm{J} 53$ or to other $\mathrm{J} 53$ clones carrying reference plasmids of other incompatibility groups. A similar superinfection immunity was found among all plasmids tested against each other; some representative examples are given in Table 4. In Tables 3 and 4 results for $\mathrm{R} 40 \mathrm{a}$ (IncC) and R446b (IncM) are included as representative examples that showed no superinfection immunity. In addition to this reduced frequency of transfer to E. coli J53 carrying the plasmid R387, a high instability of the 'doubles' between the reference type R387 and the plasmids under investigation was found (Table 3). Such an instability could not be detected among 'doubles' constructed between other reference plasmid species and the 
Table 3. Determination of incompatibility by testing superinfection immunity and the stability of 'doubles' in E. coli $\mathrm{J} 53$

Results given are from one representative experiment.

\begin{tabular}{|c|c|c|c|c|c|c|c|}
\hline \multirow{2}{*}{$\begin{array}{l}\text { Super- } \\
\text { infecting } \\
\text { plasmid }\end{array}$} & \multicolumn{4}{|c|}{$\begin{array}{l}10^{2} \times \text { No. of superinfected colonies of } \\
\text { J53 carrying the resident plasmid:* }\end{array}$} & \multicolumn{3}{|c|}{ Stability of 'doubles' with plasmid:* } \\
\hline & R387 & $\mathrm{R} 40 \mathrm{a}$ & $\mathrm{R} 446 \mathrm{~b}$ & None & R387 & $\mathrm{R} 40 \mathrm{a}$ & R446b \\
\hline pIE312 & 4 & 800 & 850 & 380 & NT & NT & $N T$ \\
\hline pIE3121 & 4 & 780 & 700 & 490 & $50 / 10$ & $50 / 50$ & NT \\
\hline pIE3122 & 3 & 860 & 620 & 590 & $50 / 5$ & $50 / 50$ & $50 / 50$ \\
\hline pIE3123 & 2 & 400 & 450 & 350 & NT & $50 / 50$ & $50 / 50$ \\
\hline pIE313 & 5 & 550 & 570 & 430 & $50 / 5$ & $50 / 50$ & $50 / 50$ \\
\hline pIE316 & 5 & 400 & NT & 350 & $50 / 8$ & $50 / 50$ & $N T$ \\
\hline pIE347 & 1 & 330 & 680 & 300 & $50 / 12$ & $50 / 50$ & $50 / 50$ \\
\hline pIE348 & 1 & 380 & 420 & 350 & $50 / 10$ & $50 / 50$ & $50 / 50$ \\
\hline pIE363 & 4 & 250 & 250 & 320 & NT & $50 / 50$ & $50 / 50$ \\
\hline pIE378 & 8 & 380 & NT & 430 & $50 / 7$ & $50 / 50$ & NT \\
\hline pIE379 & 2 & 280 & 220 & 250 & $50 / 10$ & $50 / 49$ & $50 / 50$ \\
\hline pIE380 & 3 & 450 & 400 & 440 & $50 / 8$ & $50 / 50$ & $50 / 50$ \\
\hline pIE381 & 1 & 370 & 350 & 290 & NT & $50 / 50$ & NT \\
\hline R387 & NT & 420 & 480 & 390 & NT & $50 / 50$ & $50 / 50$ \\
\hline $\mathrm{R} 40 \mathrm{a}$ & 560 & $\mathrm{NT}$ & 510 & 320 & $50 / 50$ & $\mathrm{NT}$ & $50 / 50$ \\
\hline R446b & 830 & 760 & NT & 860 & $50 / 50$ & $50 / 50$ & NT \\
\hline
\end{tabular}

NT, Not testable.

* Plasmids $\mathrm{R} 40 \mathrm{a}$ (IncC reference) and $\mathrm{R} 446 \mathrm{~b}$ (IncM reference) are included as representative examples of all reference plasmids without any superinfection immunity and complete stability of 'doubles'.

$\dagger$ Fifty colonies were replica-plated twice to select for the superinfecting plasmid and then tested for the presence of the resident plasmid. The results indicate the ratio superinfecting plasmid/resident plasmid.

Table 4. Incompatibility between the deletion mutants pIE3121 and pIE3123 and the plasmids investigated

\begin{tabular}{|c|c|c|c|c|c|}
\hline \multirow{2}{*}{$\begin{array}{l}\text { Super- } \\
\text { infecting } \\
\text { plasmid }\end{array}$} & \multicolumn{3}{|c|}{$\begin{array}{l}10^{2} \times \text { No. of superinfected colonies of } \\
\mathrm{J} 53 \text { carrying the resident plasmid: }\end{array}$} & \multicolumn{2}{|c|}{$\begin{array}{l}\text { Stability of } \\
\text { 'doubles' with plasmid: }\end{array}$} \\
\hline & pIE3121 & pIE3123 & None & pIE3121 & pIE3123 \\
\hline pIE312 & 2 & 3 & 450 & NT & NT \\
\hline pIE3121 & NT & 1 & 280 & NT & $50 / 10$ \\
\hline pIE3122 & 3 & 5 & 420 & NT & $50 / 12$ \\
\hline pIE3123 & 2 & NT & 390 & $50 / 8$ & NT \\
\hline pIE313 & 2 & 2 & 450 & NT & $50 / 5$ \\
\hline pIE316 & NT & 3 & 330 & NT & $50 / 10$ \\
\hline pIE347 & 1 & 1 & 360 & NT & $50 / 8$ \\
\hline pIE348 & 2 & 2 & 430 & NT & $50 / 8$ \\
\hline pIE363 & 4 & 4 & 600 & NT & $50 / 12$ \\
\hline pIE378 & NT & 3 & 350 & NT & $50 / 5$ \\
\hline pIE379 & 3 & 4 & 370 & $50 / 13$ & $50 / 12$ \\
\hline pIE380 & 3 & 2 & 460 & NT & $50 / 12$ \\
\hline pIE381 & 1 & 2 & 410 & NT & $50 / 9$ \\
\hline R387 & 2 & NT & 380 & $50 / 10$ & NT \\
\hline $\mathrm{R} 40 \mathrm{a}$ & 350 & 310 & 340 & $50 / 50$ & $50 / 50$ \\
\hline $\mathrm{R} 446 \mathrm{~b}$ & 490 & 540 & 540 & NT & $50 / 50$ \\
\hline
\end{tabular}

plasmids under investigation. The same instability was detected, however, among 'doubles' constructed between the various plasmids under investigation; representative results are given in Table 4. Again, results for R40a and R446b are included as representative of compatible controls (Tables 3 and 4). In summary, these results support the inclusion of the plasmids studied in the $\mathrm{K}$ incompatibility group. 
Table 5. Molecular size and the EcoRI digestion fragments of $K$ plasmid DNA

$\begin{array}{lcccc}\text { Size* } & \begin{array}{c}\text { No. of } \\ \text { EcoRI } \\ \text { sites }\end{array} & \text { Sizes of fragments after EcoRI digestion (Md) } & \begin{array}{c}\text { Sum of } \\ \text { fragment } \\ \text { sizes }\end{array} \\ \text { pIE312 } & 60 & 10 & 12 \cdot 0,12 \cdot 0 \dagger, 10 \cdot 2,9 \cdot 2,6 \cdot 5,5 \cdot 4,2 \cdot 4,2 \cdot 2,2 \cdot 0,1 \cdot 9 & 63 \cdot 8 \\ \text { pIE3121 } & 52 & 9 & 12 \cdot 0,10 \cdot 2,8 \cdot 4,6 \cdot 5,5 \cdot 4,3 \cdot 9,2 \cdot 4,2 \cdot 0,1 \cdot 9 & 52 \cdot 7 \\ \text { pIE3122 } & 54 & 9 & 12 \cdot 0,10 \cdot 2,9 \cdot 2,8 \cdot 4,6 \cdot 5,5 \cdot 4,2 \cdot 4,2 \cdot 0,1 \cdot 9 & 58 \cdot 0 \\ \text { pIE3123 } & 57 & 7 & 13 \cdot 7,12 \cdot 0,10 \cdot 2,9 \cdot 2,6 \cdot 5,5 \cdot 4,2 \cdot 2 & 59 \cdot 2 \\ \text { pIE313 } & 55 & 7 & 12 \cdot 0,12 \cdot 0 \dagger, 11 \cdot 5,8 \cdot 4,6 \cdot 5,2 \cdot 4,2 \cdot 0 & 54 \cdot 8 \\ \text { pIE316 } & 59 & 7 & 13 \cdot 7,12 \cdot 0,9 \cdot 2,8 \cdot 4,6 \cdot 5,5 \cdot 4,2 \cdot 0 & 57 \cdot 2 \\ \text { pIE347 } & 60 & 6 & 12 \cdot 0,12 \cdot 0 \dagger, 10 \cdot 2,9 \cdot 2,7 \cdot 8,7 \cdot 0 & 58 \cdot 2 \\ \text { pIE348 } & 55 & 8 & 12 \cdot 0,11 \cdot 5,9 \cdot 2,8 \cdot 4,6 \cdot 5,5 \cdot 4,2 \cdot 0,1 \cdot 9 & 56 \cdot 9 \\ \text { plE363 } & 60 & \text { ND } & & 59 \cdot 6 \\ \text { pIE378 } & 60 & 7 & 13 \cdot 7,11 \cdot 5,9 \cdot 2,8 \cdot 4,6 \cdot 5,5 \cdot 4,4 \cdot 9 & 56 \cdot 7 \\ \text { pIE379 } & 54 & 7 & 12 \cdot 0,10 \cdot 2,9 \cdot 2,8 \cdot 4,7 \cdot 4,5 \cdot 4,4 \cdot 1 & 58 \cdot 2 \\ \text { pIE380 } & 60 & 6 & 12 \cdot 0,12 \cdot 0 \dagger, 10 \cdot 2,9 \cdot 2,7 \cdot 8,7 \cdot 0 & 58 \cdot 9 \\ \text { pIE381 } & 60 & 8 & 12 \cdot 0,12 \cdot 0 \dagger, 10 \cdot 2,8 \cdot 4,6 \cdot 5,5 \cdot 4,2 \cdot 4,2 \cdot 0 & 55 \cdot 2 \\ \text { R387 } & 55 \ddagger & 7 & 13 \cdot 7,12 \cdot 0,10 \cdot 2,8 \cdot 4,6 \cdot 5,2 \cdot 4,2 \cdot 0 & \end{array}$

ND, Not determined.

* Results for CCC DNA (see Methods).

$\uparrow$ The presence of two $12 \mathrm{Md}$ fragments was concluded from the broadness of the band in the gel and from digestion studies of deletion mutants.

$\ddagger$ According to Barth et al. (1978), the size is $53.0 \mathrm{Md}$.

\section{Molecular characterization}

DNA from $E$. coli $\mathrm{J} 53$ carrying the plasmids under investigation was extracted and characterized with respect to molecular weight and to the numbers and sizes of the EcoRI cleavage fragments (Table 5). A single DNA species was detected in each $R+J 53$ clone, the plasmids ranging in size from 52 to $60 \mathrm{Md}$. The molecular sizes of the deletion mutants pIE3121 (52 Md), pIE3122 (54 Md) and pIE3123 (57 Md) indicate that a region of about $11 \mathrm{Md}$ comprises the resistance genes and that a region of about 40 to $50 \mathrm{Md}$ is occupied by other genes, such as those for transfer, replication and incompatibility. If such a large sequence is also necessary for the transfer, replication, incompatibility and maintenance functions of the other $\mathrm{K}$ plasmids, and if the other $\mathrm{K}$ plasmids identified in this paper are phylogenetically inter-related, a considerable degree of homology would be expected. We therefore attempted to determine the number of EcoRI cleavage sites and the sizes of the fragments generated. As indicated in Table 5, the number of EcoRI-sensitive sites ranged between 6 and 10 and the size of the fragments from 13.7 to $1.9 \mathrm{Md}$. The precise number of the EcoRI-sensitive sites, however, remains uncertain since we were unable in every case to identify unambiguously the number and sizes of the fragments smaller than $3 \mathrm{Md}$. However, the sums of the sizes of fragments are approximately the same as the sizes determined for the CCC DNA molecules (Table 5).

A number of the DNA fragments are identical, within the limits of our methods, in the various plasmids under investigation (Table 5). These are the fragment of sizes $12 \mathrm{Md}$ (identified in 12/13), 10.2 Md (8/13), 9.2 Md (9/13), 8.4 Md (9/13), 6.5 $\mathrm{Md}(10 / 13)$ and $5 \cdot 4$ Md (9/13). It is interesting to note that the plasmids pIE313 and pIE348 seem to be identical with respect to their molecular size, resistance pattern and genetic properties but differ in their EcoRI restriction pattern. Both plasmids originated in Sh. sonnei (Table 2) but in different countries.

The precise molecular size characterization of the different fragments and their presumed homology demonstrating a phylogenetic relatedness is under investigation. 


\section{DISCUSSION}

From Shigella sonnei, Sh. flexneri, and E. coli wild-type strains originating mainly in South-East Europe more than 70 conjugative $\mathrm{R}$ plasmids have been isolated and identified as incompatible with one another and with R387, the reference plasmid of the incompatibility group $\mathrm{K}$. These plasmids share many genetic and molecular properties and seem to constitute a closely related group. They are cotransducible by bacteriophage P1kc, are $\mathrm{Fi}^{-}$, and do not show sensitivity to the plasmid-specific phages M13, fr, Ifm, Ike, PRR1 and PRD1 in $E$. coli $\mathrm{K} 12$ substrains. The sizes of these plasmids are between 50 and $60 \mathrm{Md}$ and distinctive fragments of their DNA could be identified after digestion with EcoRI.

The precise number of EcoRI-sensitive sites in these K plasmids could not be established because smaller fragments were difficult to detect reproducibly in the gels. It should be pointed out, however, that in summing the size of fragments the total is near to that measured for the CCC DNA molecules (Table 5).

Some of the fragment sizes detected among the digested K plasmid DNA were common to most of the species investigated (Table 5). It is assumed that these fragments represent sequences coding for incompatibility, transfer or replication functions. This assumption is supported by the results obtained with the pIE312 deletion mutants (pIE3121, pIE3122 and pIE3123). The K-specific functions, e.g. incompatibility, replication and transfer, remain unaffected in these mutants and also the digestion pattern of their DNA remains almost unchanged with respect to the common fragments.

The molecular and genetic properties of the $\mathrm{K}$ plasmids described in this paper demonstrate a phylogenetic relatedness in spite of their different geographical and bacterial origin.

We thank Dr Naomi Datta for helpful discussions during the investigations and the preparation of the manuscript. One of us (H.T.) was trained in the molecular characterization of plasmids during a stay in the Department of Bacteriology, School of Medicine, Bristol. We thank Dr Peter Bennett and Professor Mark Richmond for their support. For the critical reading of the manuscript we are indebted to Professor $\mathrm{H}$. Rische, Wernigerode. The technical assistance of Christel Strauch is highly appreciated.

\section{REFERENCES}

Bachmann, B. J. (1972). Pedigrees of some mutant strains of E. coli K12. Bacteriological Reviews 36, 525-557.

Barth, P. T. \& DatTa, N. (1977). Two naturally occurring transposons indistinguishable from Tn7. Journal of General Microbiology 102, 129134.

Barth, P. T., Richards, H. \& DatTA, N. (1978). Copy numbers of coexisting plasmids in $E$. coli K12. Journal of Bacteriology 135, 760-765.

Burkardt, H.-J., Mattes, R., Pühler, A. \& HeumanN, W. (1978). Electron microscopy and computerized evaluation of some partially denatured group $\mathbf{P}$ resistance plasmids. Journal of General Microbiology 105, 51-62.

Chabbert, Y. A., Scavizzi, M. R., Witchitz, J. L., Gerbaud, G. R. \& Bouanchaud, D. H. (1972). Incompatibility groups and classification of $\mathrm{fi}^{-}$ resistance factors. Journal of Bacteriology 112 , 666-675.

Clowes, R. C. \& Hayes, W. (1968). Experiments in Microbial Genetics. Oxford: Blackwell Scientific Publications.

Coetzee, J., Datta, N. \& Hedges, R. W. (1972). R factors from Proteus rettgeri. Journal of General Microbiology 72, 543-552.

DAtTA, N. (1975). Epidemiology and classification of plasmids. In Microbiology-1974, pp. 9-15. Edited by D. Schlessinger. Washington, D.C.: American Society for Microbiology.

Datta, N. (1979). Plasmid classifications: incompatibility grouping. In Plasmids of Medical, Environmental and Commercial Importance, pp. 3-12. Edited by K. N. Timmis \& A. Pühler. Amsterdam: Elsevier North Holland Biomedical Press.

Datta, N. \& Hedges, R. W. (1972). Trimethoprim resistance conferred by plasmids in Enterobacteriaceae. Journal of General Microbiology 72, 349-356.

Datta, N. \& Hedges, R. W. (1973). R factors of compatibility group A. Journal of General Microbiology 74, 335-336.

Grindley, N. D. F., Humphreys, G.O. \& Anderson, E. S. (1973). Molecular studies of Rfactor compatibility groups. Journal of Bacteriology 115, 387-398. 
Grinsted, J., Bennett, P. M. \& Richmond, M. H. (1977). A restriction enzyme map of $\mathbf{R}$-plasmid RP1. Plasmid 1, 34-37.

Guerry, P., v. Embden, J. \& Falkow, S. (1974). Molecular nature of two nonconjugative plasmids carrying drug resistance genes. Journal of Bacteriology: 117, 619-630.

Hedges, R. W. (1974). R factors from Providence. Journal of General Microbiology 81, 171-181.

Hedges, R. W. \& DatTa, N. (1971). fi ${ }^{-}-$R-factors given chloramphenicol resistance. Nature, London 234, 220-221.

Khatoon, H., Iyer, R. V. \& Iyer, V. N. (1972). A new filamentous bacteriophage with sex factor specificity. Virology 48, 145-155.

Kontomichalou, P., Mitani, M. \& Clowes, R. C. (1970). Circular R-factor molecules controlling penicillinase synthesis replicating in $E$. coli under either relaxed or stringent control. Journal of Bacteriology 104, 34-44.

Lawn, A. M., Meynell, E., Meynell, G. G. \& DatTA, N. (1967). Sex pili and the classification of sex factors in the Enterobacteriaceae. Nature, London 216, 343-346.

LenNox, E. S. (1955). Transduction of linked genetic characters of the host by bacteriophage $\mathbf{P} 1$. Virology 1, 190-206.

Meyers, J. A., SAnchez, D., Elwell, L. P. \& Falkow, S. (1976). Simple agarose gel electrophoretic method for the identification and characterization of plasmid DNA. Journal of Bacteriology 127, 1529-1537.
Olsen, R. H. \& Thomas, D. D. (1973). Characterization and purification of PRR1, an RNA phage specific for the broad host range Pseudomonas R1822 drug resistance plasmid. Journal of Virology 12, 1560-1567.

Olsen, R. H., Siak, J. S. \& Gray, R. H. (1974). Characteristics of PRD1, a plasmid-dependent broad host range DNA bacteriophage. Journal of Virology 14, 689-699.

Roussel, A. F. \& Chabbert, Y. A. (1978). Taxonomy and epidemiology of Gram-negative bacterial plasmids studied by DNA-DNA filter hybridization in formamide. Journal of General Microbiology 104, 269-276.

Sharp, P. A., Cohen, S. N. \& Davidson, N. (1973). Electron microscope heteroduplex studies of sequence relations among plasmids of $E$. coli. II. Structure of drug resistance (R) factors and F factors. Journal of Molecular Biology 75, 235-255.

So, M., Gill, R. \& Falkow, S. (1975). Generation of a ColE1-Ap ${ }^{\mathbf{R}}$ cloning vehicle which allows detection of inserted DNA. Molecular and General Genetics 142, 239-249.

Thompson, R., Hughes, S. G. \& Broda, P. (1974). Plasmid identification using specific endonucleases. Molecular and General Genetics 133, 141-149.

TsChÄPE, H. (1973). Tet-gene pick up by an Fplasmid in Proteus mirabilis. Zeitschrift für allgemeine Mikrobiologie 13, 693-700.

TsCHÄPE, H. (1975). Zur Struktur und Entstehung der Plasmide in Enterobacteriaceae und Pseudomonas. Dissertation, Halle, G.D.R. 